judgments are merely imperatives. All these assume that any assertion that can be true or false refers to something 'in the object' and otherwise must refer to something 'in the subject'. This comes of misusing spatial metaphors. Of course, ethical judgments may be imperative, as may scientific judgments, and they are also in part subjective.

It is a pity Mr. Toulmin takes such a parochial view of the history of moral theory. 'Tradition' for him seems to be confined to three books, all of the present century, two of them negligible except as illustrating fallacies. The third, Moore's "Principia Ethica", he misunderstands through ignoring Moore's relation to Sidgwick. His few glances at the past are not happy. Bentharn is taken as initiating utilitarianism, whereas he marks an end rather than a beginning. Hume is quoted as though the outstanding exponent of moral sense. Why not Adam Smith? Above all, Mr. Toulmin ignores the fact that Plato and Aristotle were dealing with similar fallacies by methods similar to his own.

A. D. Ritchie

\section{METHOD AND PHILOSOPHY OF SCIENCE}

Science

Its Method and its Philosophy. By G. Burniston Brown. Pp. $190+8$ plates. (London: George Allen and Unwin, Ltd., 1950.) 15s. net.

$\mathrm{D}^{\mathrm{R}}$ G. BURNISTON BROWN has written a book which is full of good things. It appears to be a series of extended essays written during a period of six years and in five different places, and this may account for a sense of discontinuity which I felt when reading it. Nevertheless, there is a connecting link which the author uses to join his anecdotal treatments of a multitude of topics in the history of science: he traces the extension of scientific thought from Aristotle's "Organon" to Francis Bacon's "Novum Organum", on to Whewell's "Novum Organon Renovatum", until he comes to the "ultra-modern science" of Eddington and Milne, with which he deals in a lucid and succinct manner. Dr. Brown sees science with the eyes of a physicist who has a background of philosophy and some aspects of psychology, and this may be the reason why the ideas and methods which are more usually associated with the biological and chemical sciences have had a poor showing in his book. The author appears to neglect, and even to despise, the modern statistical methods which have been developed from the pioneer work of Galton and Pearson and which have borne such excellent fruit in the applications of biology to medicine, agriculture and the social sciences through the techniques devised by Fisher, Gosset and others.

Every author has a right to his own opinions concerning what he feels to be important, but it is doubtful whether such detailed accounts as he gives concerning the now well-known Köhler investigations on monkeys, to illustrate a process of learning, are worth including.

The whole question of the use of words in scientific thinking is a difficult one, involving as it does many epistemological problems of semantics and linguistics; but it might be worth adding Einstein's own statement concerning his method of working : "The words or the language, as they are written or spoken, do not seem to play any role in my mechanism of thought. The psychological entities which seem to serve as elements in thought are certain signs and more or less clear images which can be voluntarily reproduced and combined."

This book could profitably be read with Westaway's work of almost similar title, W. H. George's "The Scientist in Action" and C. H. Waddington's "The Scientific Attitude". If it does not occupy quite the unique place which is claimed for it on the book jacket, it is a pleasure to read ; it should be in every library and should be studied by every university student of science.

W. L. SUMner

\section{MINERALOGICAL DICTIONARY FOR CHEMISTS}

\section{An Index of Mineral Species and Varieties arranged Chemically}

With an Alphabetical Index of accepted Mineral Names and Synonyms. By Dr. Max H. Hey. Pp. $\mathrm{xx}+609$. (London: British Museum (Natural History), 1950.) $30 s$.

HOSE interested in mineralogical chemistry will welcome this book by Dr. Max H. Hey as a most useful compendium. Being based on chemical composition, the classification differs from that of other books on determinative mineralogy.

The author's introductory remarks include a state ment that his intentions are "to provide a ready answer to anyone enquiring what minerals of a given qualitative chemical composition are known, to assist in eliminating superfluous mineral names" and to provide " $a$ collective index to recent work bearing on the individuality and chemical composition of minerals". He further aims at providing an index of mineral names both old and recent. Mineral identification based entirely on qualitative chomical analysis is often difficult or impossible, but the book will be much used by those interested in the interpretation of quantitative chemical analyses of minerals, and should encourage co-operative mineralogical work by a combination of chemical and physical methods.

The work is divided into two main sections, a chemical index and an alphabetical index of mineral names. The chemical index is based on subdivision by anions; further stages of subdivision are usually by metals, with adequate cross-references, subsections being arranged according to the periodic classification of the elements. Silicates receive special treatment, being grouped according to the presence of other anions, the absence of aluminium, the presence of aluminium without other metals, and the presence of aluminium with other metals. Each mineral named is accompanied by the chemical formula or composition and by succinct notes on, for example, validity of claim to be a true mineral, varieties, synonyms, and isomorphous relationships. Bibliographical references are given, many of these being to Dana's "System of Mineralogy", the Mineralogical Magazine and Mineralogical Abstracts.

The second part of the book, an alphabetical index of mineral names, contains both literature references and numbered references to the chemical index, with names of first authors and dates of introduction of the mineral names. Synonyms and names of varieties are included in this alphabetical list. 